\title{
Arab-American Diaspora and the "Third Space": A Study of Selected Poems by Sam Hamod
}

\author{
Aseel Abdulateef Taha ${ }^{1}$ \\ ${ }^{1}$ English Department, College of Languages, Baghdad University, Iraq \\ Correspondence: Aseel Abdulateef Taha, English Department, College of Languages, Baghdad University, \\ Baghdad, Iraq.
}

Received: December 21, 2017 Accepted: February 23, 2018 Online Published: May 14, 2018

doi:10.5539/ells.v8n2p29 URL: https://doi.org/10.5539/ells.v8n2p29

\begin{abstract}
Arab-Americans are an essential part of the multi-ethnic scene in the United States of America. They are increasingly making their voices louder. However, the process of Americanization has shaped Arab-American experience and literature both directly and indirectly. The early immigrants faced the pressures of assimilation into the American society, while also trying to preserve their Arab identity in the American-born generation. Cultural issues that are related to the immigrants' experience, like biculturalism, bilingualism and dualism, are vitally depicted in Arab-American poetry. The American-born poets of Arab descent find in poetry a way through which they could express the dilemma of the Arab diaspora. Sam Hamod is one of the contemporary Lebanese-American literary figures whose works reflect the cultural conflicts from which the immigrants and their descendants suffer. Many of his poems deal with the concept of the "Third Space," presented by the post-colonial theorist Homi K. Bhabha. It is a hybrid space in which the hyphenated individuals are stuck. In the multicultural and multiracial environment of the United States, the immigrants' offspring occupy this in-between position where diverse cultures meet and clash in an endless process of identity splitting.
\end{abstract}

Keywords: Americanization, assimilation, biculturalism, cultural conflict, generation gap, split of identity

\section{An Introduction}

\subsection{America: A "Melting Pot" or a "Salad Bowl"}

The United States of America has a long history of immigration that goes back to as early as the seventeenth century and extends to the present. People from different parts of the world immigrate to America for various reasons which might be political, religious or economic. In his essay, "Immigration to the United States in the twentieth century," Roger Daniels reveals the reasons of the immigration to America:

For centuries this country has always been the traditional heaven of refuge for countless victims of religious and political persecutions in other lands. These immigrants have made outstanding contributions to American music, art, literature, business, finance, philanthropy, and many other phases of cultural, political industrial and commercial life. (Daniels, 2006, p. 6)

The racial and cultural structure of America led to the appearance of some metaphors that describe the anatomy of the American society. One of these metaphors is the "Melting Pot" (Yang, 2000, p. 85). The term was used to show assimilation: the process of taking many cultures, bringing them into America, and turning them into one culture, an American one. In this way, America is compared to a big pot, and different ethnic groups and cultures are compared to different ingredients in this big pot, where they are melted. This notion had a long tradition, dating back to the late eighteenth century. J. Hector St John Crevecoeur (1735-1813), a French American writer, wrote "Here individuals of all nations are melted into a new race of men, whose labours and posterity will one day cause great changes in the world." (Crevecoeur, 1904, p. 55)

Nevertheless, Horace Kallen (1882-1974), An American philosopher, refutes this idea by emphasizing the fact that America is a nation composed of different groups that tend to preserve many of their traditional values. Kallen in his article "Democracy versus the Melting Pot," argues that "there seems to be no domimant American mind other than the industrial and theological. The spirit of the land is inarticulate, not a voice but a chorus of many voices each singing a rather different tune" (Kallen, 1998, p. 96). Then, new metaphorical descriptions replace the "Melting Pot" metaphor, such as the "Salad Bowl" (Millet, 2013). This new metaphor shows that 
America is a mixture of various ingredients that keep their individual characteristics; immigrant populations are not blended together, rather they are transforming America into a truly multicultural society.

Lawrence Fuchs (1927-2013), a scholar of American studies and an expert on immigration policy, claims that the term "Melting Pot" ignores the persistence of ethnicity over the generations. Fuchs explains that "Salad Bowl" is not appropriate, as well, because the ingredients of a salad mix, but do not change. In his book, The American Kaleidoscope: Race, ethnicity, and the Civic Culture (1990), he suggests the "kaleidoscope" metaphor that is complex and varied in form, pattern and color. However, he declares that "No metaphor can capture completely the complexity of ethnic dynamics in the U.S." (Fuchs, 1990, p. 276). In a country formed by immigration, like America, cultures will definitely interact and oppose each other. On the other hand, multicultural and multiethnic formation results in endless variety and creativity in literary forms. Arab-Americans form an essential part of the multi-ethnic landscape in America, as there is an increase in the number of Arab immigrants to America who descend from different origins and religions.

\subsection{Arab-American Ethnicity}

The location of the Arab-Americans within the multicultural society of America is very complex. The first generation of Arab immigrants was largely composed of Christians from Mount Lebanon who tried to escape sectarian turmoil or the destruction of World War I. They easily assimilated into the American context during the late nineteenth and early twentieth century. The Lebanese historian Alixa Naff (1919-2013) states that earlier Arab-Americans might have "assimilated themselves out of existence" (Naff, 1985, p. 330). However, the subsequent generations of immigrants include people from different parts of the Arab world and with various cultural background. For later Arab immigrants, the assertion of ethnic identity, or what Charles Taylor calls "The Politics of Recognition," (Taylor, 1994, p. 75) has become essential for cultural survival.

Current Arab-American community is now facing rising forces of hostility, violence, and discrimination. Children of mixed marriages and with hybrid identities find themselves located at the margins of "Arab" and "American" identity. This ethnicity often finds itself in a cultural context that "demonizes Arab and Muslim culture while implicitly excluding Arab Americans from perceptions of "American" identity" (Majaj, 1999, p. 321). Shelly Slade, in her study carried out in 1981, illustrates the negative attitudes of Americans toward Arabs. A large proportion of respondents in the study held Arabs to be "“barbaric, cruel" (44 percent), "treacherous, cunning" (49 percent), "mistreat women" (51 percent), "warlike, bloodthirsty" (50 percent)"; similarly, respondents viewed "“most" or "all" Arabs [to be] "anti-Christian" (40 percent) [and/or] "anti-Semitic" (40 percent)." (Slade, 1981, p. 147)

The hostility toward Arabs and Muslims in the United States continues to increase during the 1990s because of political tension. Then it reaches its peak after the September 11 attacks. As Nabeel Abraham argues, "unlike other forms of racism, anti-Arab racism is often tolerated by mainstream society" (as cited in Majaj, 1999, p. 321). It appears that Arab-Americans are one of the few ethnic groups that are "safe to hate" (Ibid., 322). In response to these pressures, Arab Americans writers and thinkers have increasingly sought to assert their ethnicity. There is an important shift away from earlier generations' attempts to deny or hide their Arab identity to the cultural pride of recent Arab-Americans who have confronted the anti-Arab violence and discrimination in the contemporary American context.

For the Arab-American writers, identifying the Arab identity is a starting point from which they attempt to redefine and resituate their position in the mainstream culture. Contemporary Arab-American literature increasingly affirms the need to cross the lines of ethnicity. This reflects the growing efforts of the Arab-Americans to be a vital part of the cultural diversity. Arab-American literature has been an essential part of the literary scene in America, as there is an increase in the number of the Arab-American writers who profoundly influence American literature, in general, and American poetry in particular.

\subsection{Arab-American Poetry: An Overview}

Arab-American poetry has been part of the literature of ethnic groups in the United States since the beginning of the twentieth century. However, Arab-American poetry becomes only recently an outstanding genre in American literature. American poets of Arab descent are aware of the fact that poetry is one of the best ways through which the obstacles of race and language can be overcome. Hence, Arab-American poetry has flourished and witnessed a remarkable increase in publication. The success of Arab-American poets reflects a drastic transformation in the social, and political status of the Arabs in America who are able to create new spaces for their voices through poetry (Majaj, 2008).

The Arab-American literary tradition dates back to the literary organization, Al Rabita al Qalamaiyya (the Pen 
League), which was established in 1920 by Kahlil Gibran, Ameen Rihani and others. These authors came from what was then known as greater Syria, which included Lebanon; and they wrote in Arabic as well as in English, producing what is called Emigrant Literature or Adah al-Mahjar (Badawi, 1992, p. 96). Ameen Rihani's novel, "The Book of Khalid" (1911), and Kahlil Gibran's mystical poem, "The Prophet" (1923), are among the best selling books of all times. Al-Mahjar writers revitalize Arab poetry which serves as a bridge between East and West (Hawi, 1972, p. 13). Adab al-Mahjar has flourished in all genres, especially in poetry. Arabs have always attached great importance to poems as a means to revive their cultural values. Gregory Orfalea, a Syrian-Lebanese poet and critic, said, among Arabs, "poetry is a force of inspiration and celebration, not something that is hidden away in the academic world" (as cited in Smith, 2003).

After the 1960s, the Civil Rights and Black Power movements paved the way for the emergence of the literary voices of other ethnic groups. Arab-Americans found in literature a way through which they could reflect and revitalize their heritage (Majaj, 2008). Towards the end of the twentieth century, a new generation of ArabAmerican writers emerge. They are the descendants of immigrants, who were born and raised in America, and they hardly speak Arabic.

Today, Arab-American writers, who are more consciously involved in the politics of America, have a profound influence on American literature. However, they are still confronting certain forces which make it difficult for them to express their hyphenated identity openly. Arab-American literature is a depiction of the Arab-American life that is replete with cultural conflicts; and of the Arabs who are trying to define themselves. Arabs are excluded for their skin color, names, customs or political views that Helen Hatab Samhan has termed "political racism" (Samhan, 1987, p. 11), especially after the September 11 attacks.

The African-American sociologist, historian, and Civil Right activist, Du Bois (1868-1963), in his book, The Souls of Black Folk, diagnoses the problem of the color-line: "The Problem of the twentieth century is the problem of the color-line, -the relation of the darker to the lighter races of men in Asia and Africa, in America..." (Du Bois, 1903, p. 13) Du Bois predicts the state of split in identity in the ethnic groups at the beginning of the twentieth century. He describes the Black predicament as a form of "double consciousness," a kind of "twoness" (Ibid., p. 2), as two identities are trying to coexist within one person. Thus, African-Americans suffer a "sense of always looking at one's self through the eyes of others" (Ibid.); they are aware of being African and American at the same time. The hyphenated citizens view the world through twofold perspectives, as their ethnic roots remain an integral component of their present new identities. Du Bois states,

One ever feels his twoness, - an American, a Negro; two souls, two thoughts, two unreconciled strivings; two warring ideals in one dark body, whose dogged strength alone keeps it from being torn asunder. The History of the American Negro is the history of this strive-this longing to attain self-conscious manhood, to merge his double self into a better and truer self. (Ibid, p. 3).

\subsection{Homi Bhabha's "third space" and Rubén G. Rumbaut's "1.5 generation"}

In a multicultural environment, the clash of cultures is inevitable for the American-born child of immigrants, because the values and the traditions of the living parents stand in clear contrast to the American culture. These children are caught between two cultures, occupying a position which the Indian-American postcolonial critic Homi Bhabha defines as the "third space" (Bhabha, 1994, p. 1). According to Bhabha, the "third space" is occupied by an individual, who inhabits the location of "“in-between spaces" [that] provide the terrain for elaborating strategies of selfhood-singular or communal-that initiate new signs of identity, and innovative sites of collaboration, and contestation, in the act of defining the idea of society itself." (Ibid.) The third space is characterized by the possibility of retaining more than one culture, and the formation of a bicultural identity.

The Cuban sociologist, Rubén G. Rumbaut, refers to the American-born children of the immigrants as "1.5" or "one-and-a-half" generations, as he explains:

Children who were born abroad but are being educated and come of age in the United States from what they may be called the "1.5" generation. These refugee youth must cope with two crisis-producing and identity-defining transitions: (1) adolescence and the task of managing the transition from one sociological environment to another. The "first" generation of their parents, who are fully part of the "old" world, face only the latter; the "second" generation of children now being born and reared in the United States, who as such fully part of the "new" world, will need to confront only the former. But members of the "1.5" generation from a distinctive cohort in that many ways they are marginal to both the old and the new worlds, and are fully part of neither of them (as cited in Firmat, 1995, p. 3).

Thus, the immigrants are caught between the two cultures: the native and the new cultures. The one and a half 
generations are able to reconcile both cultures through assimilation and adaptation, but this leads to the loss of their identity. Hence, they underwent cultural struggle for their identity. In the mainstream American community, they struggle to regain their cultural identity which is lost, as they come in contact with the White culture and adopt the American lifestyle. The later generations of the Arab-American immigrants create a hybrid space among the conflicting cultural values. According to Bhabha, hybridity is regarded to be "neither the one nor the other" (Bhabha, 1994, p. 27), which means they try to reconcile between their native and the new home cultures to avoid degradation and inferiority in the new country through staying in contact with the motherland culture and traditions.

In an interview entitled "The Third Space," Bhabha states:

[F]or me the importance of hybridity is not to be able to trace two original moments from which the third emerges, rather hybridity to me is the "third space" which enables other positions to emerge. This third space displaces the histories that constitute it, and sets up new structures of authority, new political initiatives, which are inadequately understood through received wisdom (As cited in Huddart, 2006, p. 126).

The in-between space is best represented in the experience of the exile of many characters. As defined by Michael Seidel, a professor of Humanities at Columbia University, in his Exile and Narrative Imagination (1986), an exile is "someone who inhabits one place and remembers or projects the reality of another" (as cited in Ibieta, 1990, p. 68). Torn by the paradoxical realities of the United States, contemporary Arab-American poets, like Sam Hamod, live in exile. Hamod is born in the United States, but he constantly invokes images from his mother land. Meena Alexander observes that all diasporic literature is "writing in search of a homeland." (Alexander, 1993, p. 4). Being overwhelmed by his yearning for the past and his inability to fit in the present, he surrenders to nostalgia. Pramod K. Nayar says that the experience of immigration "produces nostalgia, memory, and reclamation as literary themes... the writer looks forward to the future, seeking new vistas, new chances. This produces themes of the ethics of work, survival, and cultural assimilation" (Nayar, 2008, p. 188).

\section{Sam Hamod: The Poet and the Hyphenated Identity}

Sam Hamod is one of the contemporary Arab-American authors who writes repeatedly about the experience of the immigrants in the United States of America. Hamod is regarded as one of the most influential writers in the field of multi-ethnic literature. He is also a truthful, forceful voice in mainstream American poetry. He was born and raised in Indiana in the United States of America. He is the first Muslim American poet to publish a book of poems, Beaten Stones Like Memories, in America in 1965. (Note 1) His writings stem from his roots as the son of Lebanese Muslim immigrant parents.

Hamod's poem, "Leaves" refers to grape leaves which the speaker's father picked before his death. The "Leaves" symbolize the roots which he tries to nurture with his present family. The leaves imagery recurs in the three sections of the poem. In the opening scene, Sam and his wife, "Sally," are cooking a customary eastern meal: stuffed grapeleaves. This reflects the metaphorical importance of the grape leaves as part of the cultural sustenance provided by his deceased father:
Tonight, Sally and I are making stuffed
grape leaves, we get out a package, it's
drying out, I've been saving it in the freezer, it's
one of the last things my father ever picked in this
life... we just kept finding packages of them in the
freezer, as if he were still picking them. (11. 1-6)

The "grape leaves" stands for Hamod's father as the protector of "faith" who takes extra precautions for their preservation, "packing them/ carefully," so they don't "break into pieces" (11. 9-11). In the second section of the poem, the poet is enriched culturally though reading the leaves of his father's writings which provide him with much knowledge about the Arab heritage. Hamod's father himself appears as a kind of cultural emblem. His English is poor and he speaks in a heavy accent: "To my Dar Garnchildn / Davd and Lura / From Thr Jido" (ll. 12-14). On the other hand, his Arabic letters are found everywhere upstairs.

Hamod says his father's "English lettering / hard for him to even print," is "one of the few pieces of American / my father ever wrote" (11. 17-21) The father's language is described as "American," rather than English which reflects the process of Americanization to which the Arab immigrants are subject. However, Hamod tries to preserve his father's language. This appears in the final section where the leaves are pages of "the Arabic grammar book" (1.33) 
that the speaker tries to learn in order to fully understand his father's language, and the cultural inheritance that his father has left to him: "Even now, at night, I sometimes / get out the Arabic grammar book / Though it seems so late" (11.32-34).

The immigrants cannot inhabit the past nor can they fully embrace the present. Rather, they grow in-between the past and the present. Identity formation is somehow complicated for them, as the elements of two cultures are always present. They attempt to bridge the gap between two cultures and two generations which proves to be too difficult (Bolaki, 2001, p. 139). As they assimilate into the American culture, they undergo struggles and face dilemmas. Their true identities are lost for they are divided between two diverse cultures: the culture of their ancestors and the culture of the mainstream community.

What had been lost during the process of cultural assimilation is revealed in Sam Hamod's poem "Dying with the Wrong Name" which is "Dedicated to all those who came to America and lost their names."(Hamod, 1994, p. 130) This poem reflects the suffering of the immigrants who were forced to alter their name upon arrival at Ellis Island in the late 1800's and early 1900's. Because their birth names sound "foreign" in the new country, they were obliged to "Americanize" them (Cates, 2008). The poem shows that what is lost in this forced process of re-naming is more than a name: it is a cultural identity. In becoming American, one has to be assimilated into American culture. With the inability to speak one's name, "something unspeakable is lost" (1. 23).

Hamod sheds light on the injustice of having your name forcibly altered upon entering America. Your name, that signifies your identity, is "cut" out of you. But it is not just your name that is knifed away: "the loss of your name / cuts away some other part, / something unspeakable is lost" (11. 21-3). As each name is replaced, the blood is figuratively drained and filled with American ideologies:

There is something lost in the blood,

something lost down to the bone

in these small changes.

A man in a dark blue suit at Ellis Island says, with

tiredness and authority, "You only need two names in America"

and suddenly-as cleanly

as air, you've lost your name." (11. 11-17)

The multinational experience caused some of these immigrants to experience exile and alienation. Yet, Hamod presents the immigrants as great men and women who contributed much to the American progress.

Those who opened and gave so much to America

from the sweat of their brow and work of their

hands are sadly "sealed away

with the wrong name." (11. 24-27)

The immigrants establish new rituals, father children, and form families. Legal history, a history of segregation and discrimination, shows that many immigration laws were enacted to restrict the number of the immigration flow. Although these immigrants wanted to belong, they were welcomed as sojourners not settlers. They attempted to oppose the legislation and racism, which assert that they do not belong to the United States. These people do not descend from this land, but they claim it as their new home. Who really owns the land is the man who farms it with his sweat. Crevecoeur envisions the American citizen as the one who leaves "behind all his ancient prejudices and manners, [and] receives new ones from the new mode of life he has embraced" (Crevecoeur, 1904, p. 54).

Immigration changes people and their mentalities. Experiences that result from immigration are the outcome of the mixing of multiple influences and peoples. Consequently, these new experiences lead to different representations of self-identity. Such representations are manifested in cultural forms, like new forms of literary production, new kinds of food, new styles of music, and new styles of dress (King, Connell, \& White, 2003, p. 1). The immigrants try to adapt to the American culture by adopting the American lifestyle: "you move / about as an American" (11. 19-20) with "a cigar store in Michigan City, and / in the back room a poker game with chips and / bills..." (11. 27-29). Their favorite music becomes "B. B. King and T-Bone Walker" (1. 39), and they "buy time": "each dollar another day mixing names and money" (1. 40). They toil and "from / nothing to houses and apartments worth more than / a million - in each sweaty day in Sioux City" (11. 33-5). 
Immigrants mimic and imitate the Americans. Mimicry appears when members of a minority group imitate and adapt to the culture of the majority. As Bhabha (1949- ) argues, mimicry is "the desire for a reformed, recognizable Other, as a subject of a difference that is almost the same, but not quite" (Bhabha, 1994, p. 86). He states that there is a "demand for a model, a tradition, a community, a stable system of reference" (Ibid., p. 109), so that any culture can be identified by others. S/he will preserve some elements of her or his origin, even if s/he identifies herself or himself as an American. Bhabha sees such imitation as an "on-going negotiation that seeks to authorize cultural hybridities that emerge in moments of historical transformation" (Ibid., p. 7).

But then the immigrants die to be buried "under / a stone carved in English" (11. 47-48). They remain outsiders in the American mainstream culture. The poem communicates the dramatic effects of loss for these immigrants.

These men died with the wrong names,

Na'aim Jazeeny, from the beautiful valley

of Jezzine, died as Nephew Sam,

Sine Hussin died without relatives and

because they cut away his last name

at Ellis Island, there was no way to trace

him back even to Lebanon ... (11. 1-7)

Sam Hamod's "After the Funeral of Assam Hamady," reflects the complexities in a contemporary, diasporic Arab-American identity. Hamod begins the poem with providing the readers with information about the characters and the setting:

Cast:

Hajj Abbass Habhad: My grandfather

Sine Hussin: an old friend of my father

Hussein Hamod Subh: my father me 6 p.m. middle of South Dakota. (11. 1-7)

The "Cast" suggests that the characters are acting in an American movie. The narrator of the poem is "me," Sam Hamod, who is "driving the 1950 Lincoln/ninety miles an hour" (11. 7-8). Hamod's car is named after the most well-favored president in American history, Abraham Lincoln (1809-1865). (Note 2)

With Stern tone, the old men demand that the car should be stopped to pray on a highway in South Dakota after attending the burial of their old friend, Assam Hamady:

"STOP! STOP! Stop this car!"

Why?

““'STOP THIS CAR RIGHT NOW!”-Hajj Abbas

grabbing my arm from the back seat:

"Hysht lyat? (What're you yelling about?)" - my father

Shu bikkee?" (What's happening?)- Sine Hussin ...

I stop

"Its time to pray, sullee

the sun sets

time for sullee ... (11. 12-21)

The poet is disturbed by the old men's orders to stop the car for a prayer. Obviously, a generation gap is reflected in the poem. The poem conveys to the reader the various thoughts and emotions of all the characters, especially Hamod as a young American of Middle Eastern ancestry. For the young Lebanese-Americans, there is something odd in the act of praying in the middle of South Dakota. Because he was brought up in the United States, he has difficulty in understanding the rituals of his religion. The religious custom seems to be of no importance to him.

On the other hand, the use of the Arabic language and the major Islamic prayer, "Al Fati'ha," makes of the poem an authentic experience that strongly reflects the cultural identity of the older gentlemen. Clearly, a difference exists between Hamod and the older generation. They are not as culturally assimilated as he is. When the old men begin their Muslim rituals, Hamod remains "sitting behind the wheel" (1. 25) while "car lights scream by" (1. 27). They 
ask him to pray with them, but he declines: “'Hamod! Get over here, to pray!” / No, I'll watch/ and stand guard” (1l. 25-27). Hamod's confesses that he becomes too Americanized to be part of the religious ceremonies of his prior culture.

Different factors cause the perplexity of the speaker, one of them is religion. The narrator's position between two worlds is the reason for his inability to understand the role of religion in life. Hence, he feels that he is spiritually and emotionally detached from the prayer of the old men. This indicates how large the gap is between the first and the second generation. The poem articulates the tension between the bicultural, bilingual immigrants and the thoroughly Americanized second generation. The member of the second generation chooses to incorporate the conflicting elements of two diverse cultures within her/his identity. Bhabha calls such person as "a subject that inhabits the rim of an in-between reality" (p. 13).

The act of praying, which is the primary action of the poem, signifies the old men's strong cultural ties with their mother culture. As they are praying "people stream by, an old woman strains a gawk at them" (1.73) and Hamod is embarrassed by this public performance of religious rituals:

Three old men

chanting the Qur'an in the middle

of a South Dakota night

Allahu Ahkbar

Allahu Ahkbar...

in high strained voices they chant

more cars flash by...

I'm embarrassed to be with them (11. 57-61)

However, Hamod reveals a strong sense of nostalgia as he regrets his inability to join the old men in their act of praying. He feels something important has been lost:

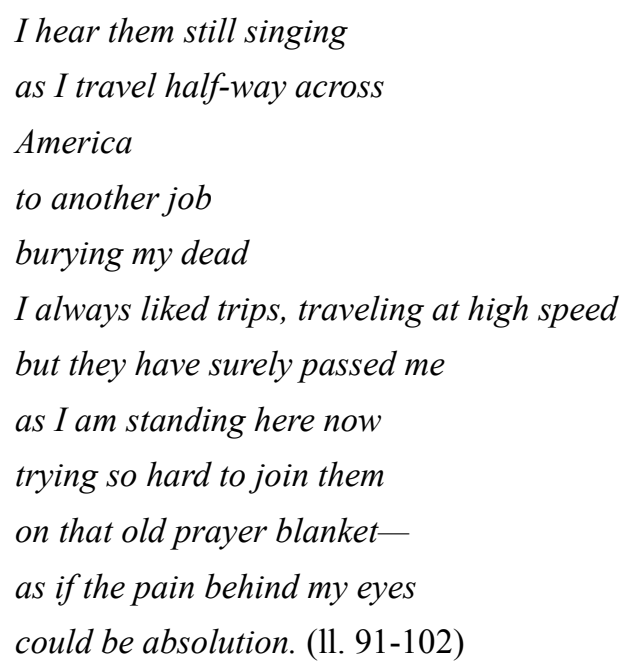

Hamod, after this experience, finds himself fluctuating in his cultural tendencies. He feels that his ancestors have "passed" (1. 97) him and he missed the chance "to join them / on that old prayer blanket" (11. 99-100) to restore his lost roots. He has been entrapped in the process of Americanization. A conflict arises from being located in this in-between situation. This conflict lies in the fact that he is neither able to reject the old culture fully, nor is he capable of embracing the new one.

"From Moving" depicts the state of cultural fluctuation that results from moving or leaving one's country. As Edward Said mentions, in his book Orientalism, "Many travelers find themselves saying of an experience in a new country that it wasn't what they expected, meaning that it wasn't what a book said it would be" (Said, 1994, p. 93). Hamod's emphasizes that the immigrants suffer emotional instability and restlessness, and finally they might be lost in-between. To substantiate the ideas about being culturally lost, Hamod uses the sea imagery. The poet and the members of his family are metaphorically described as "shipmates" (1.4) who are separated from each other by the waves of the stormy sea. They are all lost at sea. The wife and the children are calling for the father's help, but he could do nothing to help them. He himself is lost in the middle of nowhere: 
so we move now

my new wife and I, my children

move further away

like lost

shipmates crying to me for help (11. 1-4)

The addition of extra spaces is intended to indicate the strong sense of being displaced and "lost" in the endless chaos of the new world. The poet shows that "trying to grasp at these new patterns in the early morning darkness" (1. 8) is like striving to float on the surface of a giant wave. In the beginning, the immigrant family has moved like "the whole tribe moved together." (1. 23) The union of the members of the displaced family is emphasized. However, in the end, the violent current of Americanization carries the displaced children away from the mother culture. This is actually what has happened to Hamod himself during his childhood. Hamod states:

\section{I sometimes think about a life \\ in some old country of time that I remember my father and \\ grandfather \\ talking about, when I kept wanting to go out and play baseball. (11. 17-20)}

Like a typically American child, he preferred playing "baseball" to listening to the talk of his Arab ancestors. Usually the immigrants try their best to re-root the traditions of their "old country" in their uprooted children but in vain. Alfred Schutz, an Austrian social scientist, believes that the immigrant is a stranger who is "a cultural hybrid on the verge of two different patterns of group life" (Wagner, 1970, p. 94). The culturally hybrid children become too Americanized to maintain the customs of their homeland. Furthermore, they suffer a confused state of mind and socio-cultural dualism.

Cultural differences are often represented as a generation gap in the sense that older generations are at odd with their "Americanized" children (Cowart, 2006, p. 7). The great freedom that young people enjoy in the USA is a source of clash with their conservative parents; that is why the theme of generation gap is largely dealt with by immigrant writers, reflecting the generation clash which marks both the partial and gradual loss of the old culture and the definitive transition to "Americanness" (Ibid., p. 86). However, the immigrant's child constantly attempts to decide who to be and takes into consideration the culture of her/his parents when $\mathrm{s} / \mathrm{he}$ tries to find a place in the mainstream culture. In Boundaries of the Self: Gender, Culture, Fiction, Roberta Rubenstein, a professor of literature, points out: "[The immigrants'] offspring born in America inherit this split between cultures without ever having seen their ancestral land, except imaginatively, through their elders' eyes" (Rubenstein, 1987, p. 166).

\section{Conclusion}

America is a country where diverse cultures clash. In this metaphorical big pot, the meeting of two cultures creates a third space, where individuals attempt to compromise between the differences of two cultures through mimicry, remembrance, and reconciliation. Paradoxes shape the life of the members of a racial minority group who are exposed to different cultural influences. They may either be defensive aiming to preserve the cultural values of their home origin, or they may fully assimilate into the dominant culture. They are stuck in this in-between position where the search for their identity is a never ending process. They sometimes yearn for their mother land; and at other times, they attempt to belong to the United States. Even though they mimic white Americans, they always maintain their literary heritage and their family ties. In Bhabha's opinion, "It is a negotiation rather than negation... that makes it possible to conceive of the articulation of antagonistic or contradictory elements" (p. 25). The identity of a person in a minority ethnic group admits the existence of cultural differences. This might lead to identity splitting, as the bicultural identity includes two distinct parts each of which becomes dominant from time to time.

Having been placed between two cultures, the one and a half generations occupy a third space where cultures meet and collide. According to Bhabha, the "in-between spaces" are the locale of contact between diverse cultures, which help to "initiate new signs of identity and innovative sites of collaboration" (pp. 1-2). He argues that it is "the in-between space that carries the burden of the meaning of culture" (p. 38). To highlight how critical is the third space in which the immigrants are situated, a new literary production is presented. Arab-American literature is where eastern and western ideas meet and interact. It incorporates two different worlds, the old and the modern. According to Bhabha, "such art does not merely recall the past as social cause or aesthetic precedent; it renews the past refiguring it as a contingent "in-between" space, that innovates and 
interrupts the performance of the present. The "past-present" becomes part of the necessity, not the nostalgia of living" (p. 7).

Literature of multicultural and multiracial nature embraces cultural differences as a source of creativity and cultural enrichment, rather than an impoverishment of cultural identity. Thus, the third space proves to be productive, because in this space cultural values are constantly renewed. According to Bhabha, the third space challenges the inherent supposition that cultures are pure and authentic. It is occupied by an individual, who inhabits the location of "“in-between spaces" [that] provide the terrain for strategies of selfhood-singular or communal-that initiate new signs of identity, and innovative sites of collaboration, and contestation, in the act of defining the idea of society itself' (p. 1). The third space is characterized by the possibility of retaining more than one culture, and the formation of a bicultural identity. Henry Levin, an American critic, notes that "the most creative minds are those capable of keeping that other world in sight" (Levin, 1966, p. 180).

As an innovative Arab-American writer, Sam Hamod frequently deals with critical cultural issues in a rhythmical and simple style. Pablo Neruda, a Chilean poet, states that" There are few poets who combine emotion, rhythm, clarity and language in the way of the American poet, Sam Hamod." (Note 3) Hamod is a cosmopolitan poet who speaks from a position that encompasses many voices regardless of race. His poetry acts as a mirror reflecting many injustices that he sees throughout the world. He is unique in his genuineness and cultural diversity. His poems explore the contradictories of multiculturalism in contemporary America.

\section{References}

Alexander, M. (1993). Fault Lines: A Memoir. New York: The Feminist Press.

Ashcroft, B. (2000). Gareth Griffiths, \& Helen Tiffin. Postcolonial Studies: The Key Concepts. New York: Routledge.

Badawi, M. M. (1992). Modern Arabic Literature. Cambridge: Cambridge University Press.

Bhabha, H. K. (1994). Location of Culture. New York: Routledge.

Bolaki, S. (2011). Unsettling the Bildungsroman: Reading Contemporary Ethnic American Women's Fiction. Amsterdam: Rodopi B. V.

Cates, A. L. (2008). The World Comes Together: Dual Identity in the Poetry of Sam Hamod. Fringe, Issue 17. Retrieved from http://sundresspublications.com/fringe/lit/criticism/the-world-comes-together-dual-identity-in-the-poetry-of -sam-hamod/

Cowart, D. (2006). Trailing Clouds: Immigrant Fiction in Contemporary America. New York: Cornell University Press.

Crevecoeur, J., \& Hector St, J. (1904). Letters from an American Farmer. Massachusetts: Applewood Books.

Daniels, R. (2006). Immigration to the United States in the Twentieth Century. In C. Bigsby (Ed.), The Cambridge Companion to Modern American Culture. Cambridge: Cambridge University Press. https://doi.org/10.1017/CCOL0521841321.004

Du Bois, W. E. B. (1903). The Souls of Black Folk. New York: Dover Publications.

Firmat, G. P. (1995). Life on the hyphen: The Cuban-American way. Austin: University of Texas Press.

Fuchs, L. (1990). The American Kaleidoscope: Race, Ethnicity, and the Civic Culture. Middletown: Wesley University Press.

Gilla, M. M., \& Gillan, J. (1994). Unsettling America: An Anthology of Contemporary Multicultural Poetry. New York: Penguin Books Ltd.

Hamod, S. (1994). Unsettling America: An Anthology of Contemporary Multicultural Poetry. In M. M. Gillan \& J. Gillan (Eds.). New York: Penguin Group.

Hawi, K. S. (1972). Kahlil Gibran: His Background, Character and Works. Beirut: Arab Institute of Research and Publishing.

Huddart, D. (2006). Homi K. Bhabha. London: Routledge Taylor \& Francis Group. https://doi.org/10.4324/9780203390924

Ibieta, G. (1990). Transcending the Culture of Exile: Raining Backwards. In D. Bevan (Ed.), Literature and Exile. Amsterdam-Atlanta, GA. 
Kallen, H. M. (1998). Democracy Versus the Melting Pot. In H. M. Kallen (Ed.), Culture and Democracy in the United States. New Jersey: Transactions Publishers.

Levin, H. (1966). Refractions: Essays in Comparative Literature. Oxford: Oxford University Press.

Majaj, L. S. (1999). Arab-American Ethnicity: Locations, Coalitions, and Cultural Negotiations. In M. W. Suleiman (Ed.), Arabs in America: Building a New Future. Philadelphia: Temple University Press.

Majaj, L. S. (2008). Arab-American Literature: Origins and Developments. Retrieved from http://www.asjournal.org/52-2008/arab-american-literature-origins-and-developments/

Millet, J. (2003). Understanding American Culture: From Melting Pot to Salad Bowl. Retrieved from $\mathrm{http} / / /$ www.culturalsavvy.com/understanding_american_culture.htm

Naff, A. (1985). Becoming American: The Early Arab Immigrant Experience. Carbondale, IL: Southern Illinois University Press.

Nayar, P. K. (2008). Postcolonial Literature: An Introduction. Delhi: Longman.

Rhodes, L. (2010). The Ethnic Press: Shaping the American Dream. New York: Peter Lang Publishing, Inc. https://doi.org/10.3726/978-1-4539-0015-4

Rubenstein, R. (1987). Boundaries of the Self: Gender, Culture, Fiction. Urbana and Chicago: University of Illinois Press.

Russel, K., Connell, J., \& White, P. (2003). Writing Across Worlds: Literature and Migration. New York: Routledge.

Rutherford, J. (1998). Identity: Community, Culture, Difference. London: Lawrence \& Wishart Limited.

Said, E. (1994). Orientalism. New York: Random House, Inc.

Samhan, H. H. (1987). Politics and Exclusion: The Arab American Experience. Journal of Palestine Studies, 16(2), 11-28. https://doi.org/10.2307/2537085

Scott, K. (2016). Speaking for Others: The Poetry of Sam Hamod. Retrieved from http://contemporaryworldliterature.com/?p=1320

Slade, S. (1981). The Image of the Arab in America: Analysis of a Poll on American Attitudes. Middle East Journal, 35(2), 143-162.

Smith, D. (2003). Arab-American Writers, Uneasy in Two Worlds; Immigrant Authors Feel Added Burdens Since 9/11. Retrieved from http://www.nytimes.com/2003/02/19/arts/arab-american-writers-uneasy-two-worlds-immigrant-authors-feel -added-burdens.html

Taylor, C. et al. (1994). Multiculturalism: Examining the Politics of Recognition. Princeton, NJ: Princeton University Press.

Wagner, H. R. (1970). Alfred Schutz on Phenomology and Social Relations. Chicago: University of Chicago Press.

Whitlark, J., \& Wendell, M. A. (1992). The Literature of Emigration and Exile. Lubbock, Texas: Texas Tech University Press.

Yang, P. Q. (2000). Ethnic Studies: Issues and Approaches. New York: State University of New York.

\section{Notes}

Note 1. https://www.poetryfoundation.org/poets/sam-hamod

Note 2. http://www.history.com/topics/us-presidents/abraham-lincoln

Note 3. http://contemporaryworldliterature.com/?p=1320

\section{Copyrights}

Copyright for this article is retained by the author(s), with first publication rights granted to the journal.

This is an open-access article distributed under the terms and conditions of the Creative Commons Attribution license (http://creativecommons.org/licenses/by/4.0/). 